\title{
THE COURTS AND THE ROBINSON-PATMAN ACT: POSSIBILITIES OF STRICT CONSTRUCTION
}

\author{
James Angrll McLaughlin*
}

So much has been written concerning the construction of the Robinson-Patman Act in the light of its history in the halls of Congress that further discussion might seem sterile until authoritative interpretations are forthcoming. Comparatively little attention has been paid to the broader background of legislation directed toward the end of trade regulation and to the treatment of such legislation in the courts. The outstanding fact is that the courts have consistently resisted all pressure to construe such legislation in any manner which does not preserve to the business man wide latitude to conduct his business and to the courts wide latitude to direct legal restraint with reference to judicial concepts of the proper sphere of government and with reference to judicial instincts concerning public policy.1

A quarter century ago Mr. Justice Harlan trembled for the safety of our institutions, because the Sherman Law had, for the first time, just been declared to prohibit only unreasonable restraints of trade. ${ }^{2}$ The Standard Oil decision marked a frank recognition of the fact, repeatedly denied in earlier opinions, that the broad language of the Sherman Law would be applied only within reasonable limits. No machinery for determining the limits was available except judicial judgments founded to a large extent on silent major premises. State laws were either forced substantially into the mould of the Sherman Law or declared unconstitutional. ${ }^{3}$ Agitation after the Standard Oil opinion led to the exploration of uncharted fields and some federal legislation resulted in I9r4. ${ }^{4}$ But those who supposed that the Federal Trade Commission, then established, could develop new law on matters of major public policy were due to a rude awakening. The courts emphatically announced from the outset

- A.B., 1912, University of Michigan; LL.B., 1916, Harvard University. Member of the Illinois Bar. Professor of Law, Harvard Law School. Author of Cases on the Federal Anti-Trust Laws. Contributor to legal periodicals.

${ }_{1}^{1}$ The thesis that substantially all legislation in this field is either declaratory or unconstitutional has been developed with manifold illustrations. See Montague, Proposals for Revision of Anti-Trust Laws, in Handler, The Federai Antr-Trust laws, a SyMpositim (x932) 23.

${ }^{2}$ See Standard Oil Co. of N. J. v. U. S., 221 U. S. I, 105 (1911).

${ }^{3}$ International Harvester Co. v. Kentucky, 234 U. S. 216 (19r4); Cline v. Frink Dairy Co., 274 U. S. 445 (1927); Fairmont Creamery Co. v. Minnesota, 274 U. S. I (1927); Williams v. Standard Oil Co., 278 U. S. 235 (I929); and see Montague, supra note I, at $39-48$.

'The Federal Trade Commission Act of Sept. 26, 1914, 38 Stst. 717, and the Clayton Act of Oct. 15, 1914, 38 STAT. 730. 
that they, not the Commission, were to declare the law ${ }^{5}$ and the Commission was dric en chiefly into the pursuit of "the small dishonesties of trade" ${ }^{\text {and }}$ ane search of information, with narrowly limited powers to collect such information as might no. be readily forthcoming. ${ }^{\text {It }}$ did help to mould the law of resale price maintenance, ${ }^{8}$ for what it may be worth, ${ }^{0}$ but the meaning of the Anti-trust Laws continued to be determined by the Supreme Court and, as an auxiliary agency for the enforcement of the law so determined, the Commission was compelled to assume a very minor rôle.

No exception was made with reference to the Clayton Act, which was the companion of the Federal Trade Commission Act. Indeed, the history in the Court of the Clayton Act, to which the Robinson-Patman Act is most closely linked, may be regarded as the key to the present situation. The "Magna Charta"10 of labor contained in that law was found to comprise only innocuous abstractions or provisions "merely declaratory of what was the best practice always." 11 The section against tying clauses was employed to check a growing practice on the part of patentees to extend their monopolies into unrelated fields, ${ }^{12}$ but, otherwise, strict construction ruled.

A section of the Clayton Act prohibited stock acquisition where the effect might be to lessen competition substantially "between the corporation whose stock is so acquired and the corporation making the acquisition." 13 This, on its face, is in contrast to the other passages in the Act which refer to lessening competition or tendency to create a monopoly in any line of commerce. ${ }^{14}$ It would thus appear that, where one corporation acquires control of another corporation with which it has been in competition as to a substantial part of its business, competition would be lessened substantially between the two corporations. Attention is directed to the two corporations as a closed system with reference to which the substantial character of the

${ }^{5}$ The leading case is F. T. C. v. Gratz, 253 U. S. 421 (1920). Reaffirmations of this announcement in the Circuit Courts of Appeals have been too numerous to warrant citation.

${ }^{\circ}$ Mr. Justice Holmes used the quoted words. In their context they suggest that calmness slightly tinged with scorn which is sometimes known as Harvard indifference. See Nash v. U. S., 229 U. S. 373, 378 (1913). By 1930 over $90 \%$ of Federal Trade Commission complaints charged false advertising, false branding and the like. See Watkins, Federal Trade Commission and the Anti-Trust Laus, in HANDLER, op. cit. supra note 1 , at 113 . The proportion has tended to inerease rather than decrease.

${ }^{7}$ F. T. C. v. Am. Tobacco Co., 264 U. S. 298 (1924); F. T. C. v. Claire Furnace Co., 274 U. S. 160 (1927).

${ }^{8}$ Pursuant to its victory in F. T. C. v. Beech-Nut Packing Co., 257 U. S. 44 I (1922).

- For a brief summary of the leading cases and the economic bearing of the law, see discussion by McLaughlin at Round Table Conference on Law and Economics (1929) I9 AM. Ecos. Rev. Supp. 56.

${ }^{20}$ Samuel Gompers used this expression about $\$ 6$ of the Clayton Act. See Charter of Industrial Freedom (1914) 2 I Am. Federationist, 957, 97I; Frankfurter and Greene, the Labor Injunction (I930) I $42-143$.

${ }^{11}$ Per Taft, C. J., discussing $\$ 20$ in Am. Steel Foundries v. Tri-City Central Trades Council, 257 U. S. I84 (rg21).

${ }^{22}$ See Motion Picture Patents Co. v. Universal Film Mfg. Co., 243 U. S. 502, 515 (1917); Note, Repudiaion of Patent Protection by Extension of $\$ 3$ of the Clayton Act (193I) 40 YALE L. J. 954 .

${ }^{\text {n3 }} 57,38$ STAT. 73 I (I9I4).

14 The reference to the line of commerce occurs in $\$ 7$ in connection with tendency to create a monopoly as distinct from lessening competition and occurs in $\$ \$ 2$ and 3 in both connections. 
effect is to be gauged. It would appear unnecessary that the effect be substantial compared with the entire volume of the "line of commerce" throughout the United States. Such a construction would carry out the theory upon which this portion of the Clayton Act was passed-that it is sound policy to nip trusts in the bud by prohibiting certain peculiarly invidious or potent methods of eliminating competition, and so to arrest the growing power before it reaches the stage where substantial impairment of the competitive structure of a "line of commerce" has already been achieved. ${ }^{15}$ The Supreme Court, however, not only ignored the construction outlined, but upset an order of the Federal Trade Commission which was based upon substantial evidence that competition in the entire shoe business had been lessened substantially. ${ }^{16}$

Section 2 of the Clayton Act, ${ }^{17}$ which is amended by Section I of the RobinsonPatman Act, has also been narrowly construed. A Circuit Court of Appeal delayed its operation for years by erroneous reference to legislative history. ${ }^{18}$ Eventual correction of this error of law by the Supreme Court ${ }^{19}$ led to the recovery of substantial damages founded upon serious price discrimination, ${ }^{20}$ but the section has never been given any extensive application. The most conspicuous case of local price discimination evidencing monopolistic price control has been the "Pittsburgh Plus" system of delivered prices in the steel industry, but the Federal Trade Commission deemed it wise to accept an inglorious compromise when its order to abandon the practice was only complied with so far as the United States Steel Corporation deemed "practicable."21 Complaints that the section is innocuous because of weakening provisos confront the fact that a state statute which flatly forbade price discrimination was declared unconstitutional. ${ }^{22}$

An undertone of adverse criticism may be thought to accompany the foregoing broad summary of the decisions in the background of the Robinson-Patman Act. The time and the occasion may arise when something must be done to curb judicial dominance in the field in question. But whether or not the time has come, it is submitted that the Robinson-Patman Act does not offer the occasion. Desirable as

\footnotetext{
${ }^{25}$ See Wooley, J., dissenting in Temple Anthracite Coal Co. v. F. T. C., 51 F. (2d) 656 (C. C. A. 3d, 1931); Henderson, Federaz Trade Commission (1924) 39; Mclaugrilin, Cases on the Federal. ANTI-TRust Laws (1933) 301, n.94, 315, n.99.

${ }^{10}$ International Shoe Co. v. F. T. C., 280 U. S. 29 I (1930). Mr. Justice Stonc's dissent and the discussion of the evidence in the Court below secm more convincing. See 29 F. (2d) 5 I 8 (C. C. A. Ist, Ig28).

${ }^{17}$ Stspra note 4 .

${ }^{13}$ Mennen Co. v. F. T. C., 288 Fed. 774 (C. C. A. 2d, 1923); National Biscuit Co. v. F. T. C., 299 Fed. 733 (C. C. A. 2d, I924). Both decisions probably arrived at the right result, however, since the functional discounts of the Mennen case and the quantity discounts of the National Biscuit case buth scem proper.

${ }^{23}$ Van Camp \& Sons v. Am. Can Co., 278 U. S. 245 (1929).

${ }^{20} \mathrm{Am}$. Can Co. v. Ladoga Can Co., 44 F. (2d) 763 (C. C. A. 7th, 1930) cert. denied, 282 U. S. 899 (r93r).

${ }^{2}$ F. T. C. v. U. S. Steel Corp.,-8 F. T. C. I (1924); Fetrer, Masquerade of Mo:apoly (1931) 158; Note, Legality of Basing-Point Systems (1932) 45 Harv. L. Rev: 548; N. R. A. Report, Operation of the Basing-Point System in the Iron and Steel Industry (1934); Fed. Trade Comm'n, BasingPoint System in the Steel Industry (1935); Burns, The Decline of Competition (1936) 299-322.

${ }^{2}$ Fairmont Creamery Co. v. Minnesota, 274 U. S. I (1927).
} 
the Sherman Act may be, the point of view of the business man is intelligible when he complains of having the uncertainties of law added to the difficulties of making pressing business decisions. There is even some force to his complaint when the problem confronted is a merger or a trade association program directed toward the mitigation of "cutthroat competition" or "disorderly markets," but a decision to merge may be made only once in a corporate lifetime and in most cases the danger zone in trade association activity may be avoided by him who is really ready to accept the clearly announced principle that monopolistic control of markets is only to be allowed under government supervision. The greatest pressure to which the modern business man is usually subjected, however, is the pressure to sell his goods. Conditions change, markets shift, customers switch and the risk of not being able to meet his payroll may necessarily overshadow all fears of legal interference with his accustomed liberty to make his sales as best he can. Force, fraud and conspiracy he knows he must avoid. But to make allowances to customers only on "proportionally equal terms"! No one can tell him how to do that and, if he makes no allowances at all, he is going to lose business to his bolder competitors.

The impractical vagueness of the law which may confront the seller at every turn in a long business day renders it an outrageous basis for a suit for triple damages. The triple damage suit was devised to inculcate the fear of the Lord into the predatory trust. It may not apply to the Robinson-Patman Act at all, ${ }^{23}$ but the general impression that it does so apply can scarcely operate to warm the welcome with which that loosely knit enactment is received in the courts.

The history of the Act as an anti-chain store bill ${ }^{24}$ is not in its favor. It represents a raid by selfish interests attempting to uphold obsolescent and inefficient methods of distribution against the chief contribution of the current generation toward making the purchasing power of the masses effective. Its proponents align themselves with those short sighted agitators who from time to time have opposed the introduction of labor saving machinery. ${ }^{25}$ It further represents a generalization from a small amount of data-the typical error of the business man thinking of all creation in terms of his trade. Upon the analogy of the $V$ an $C_{a m p}$ case $^{26}$ it may well be thought that the great bulk of the references to the immediate Congressional history of the Act will be properly held inadmissible. In view of all these considerations it seems worth while to explore the possibilities of strict construction.

We shall first direct our attention to Section $\mathrm{I}$ of the Act, constituting Section 2 of the Clayton Act as amended. It may first be noticed that the Act does not prohibit differences or differentials in price, although Congress showed its consciousness of the availability of the two last mentioned words by employing them in one of the provisos of the paragraph. What the statute does prohibit relates to discrimination in price. Now discrimination is a word that has an offensive connotation. Consequently, if

\footnotetext{
${ }^{23}$ See infra p. 419.

* See SEs. Doc. No. 4, 74th Cong., Ist Sess. (1935); (1936) 50 Hazv. L. REv. 106.

- See Burns, Book Review (r937) 46 Yale L. J. 909, 911.

- Sispre note Ig.
} 
the court finds that the price differences are not undue or are only reasonable, it may hold that such differences constitute no discrimination. Provisos shortly to be discussed which specify circumstances in which discrimination may be lawful obviously do not preclude this construction. It may next be noticed that discriminations in price are only prohibited between purchasers of like grade and quality. Consequently, if the grade and quality differ even though the price difference may be so large as to suggest a discrimination, such a discrimination is not within the letter of the Act. ${ }^{27}$

Section 2 of the original Clayton Act applied to all sales in the course of interstate commerce. Under this provision discrimination in local sales which directly and substantially affected interstate commerce was unlawful. The additional requirement has been added that one or more of the purchases be in interstate commerce, thus suggesting that discrimination in local sales is excluded, whatever the effect. Reference to the course of commerce suggests the concept of the flow of commerce which has been frequently used to tie local transactions in with interstate transactions. The more specific added language may serve only to restrict the broad application of this concept, although only a background favorable to strict construction would induce such a fine spun argument.

The language of the statute admits of outright sabotage of the intention which would be usually attributed to the use of such words in ordinary conversation. It applies only to goods sold for use, consumption or resale in the United States. If chattels are sold without any specification of the purpose for which they are used, then they are not literally sold for use, consumption or resale within the United States. Even if the buyer contemplates using them or selling them in the United States, that is no concern of the seller. The articles are sold outright and not for any limited purpose. They may be bought for use, consumption or resale within the United States, but that is irrelevant. The fact that this argument has not been applied to the old Clayton Act would not exclude its application here if the new Act seems more drastic in other respects.

Even if there is a difference in price amounting to an undue or unreasonable discrimination where goods of like grade or quality are sold across state lines under stipulations that they be used or resold in the United States, there is no violation of the Robinson-Patman Act unless the old tests of Section 2 about substantial lessening of competition or tendency to create a monopoly are satisfied or unless the effect may be to "injure, destroy or prevent competition" with any person who either grants or receives the benefit of the discrimination. Note that it is only when the effect upon competition with the parties or their customers is drastically affected that this last clause is satisfied. Competition is rarely "destroyed" or "prevented." These words are in marked contrast to the phrase "substantially lessen" which is

\footnotetext{
${ }^{n}$ It may be doubted whether this marks any practical change from the Clayton Act, since it would be difficult under either law to establish discrimination between the purchasers of different grades of merchandiee. See Melaughlin, Book Review (1937) 23 VA. L. REV. 860, 861.
} 
carried over from the old Clayton Act. Even the word "injure" is a comparatively harsh word, and, with the application of the maxim noscitur a sociis, it may readily be construed as referring only to a high degree of impairment. If Congress intended to cover discrimination which simply impaired competition, it might readily have said so. On the whole it is easy to conclude that proof of injury, destruction or prevention of competition within the meaning of the Robinson-Patman Act will be adduced so infrequently that the clause in question does not substantially extend the area covered by the Clayton Act.

Coming now to the provisos, it may be observed that provisos cannot add to the positive provisions of the principal clauses or paragraphs to which they are annexed without violating an elementary principle of statutory construction. Most of the provisos in this law may be safely disregarded as merely declaratory of lawful differences in price which would not violate the law in any case. They cannot legitimately be construed to enlarge the law by negative inferences. The clause purporting to give power to the Federal Trade Commission, however, to fix "quantity limits" above which further quantity discounts will not be allowed is not a proper proviso. It will probably be accepted as an attempt to add to the substantive law. Such limits are to be set with reference to differentials which make only due allowances for differences in cost. In order to set such limits the Federal Trade Commission must find either that such a differential is "unjustly discriminatory" or "promotive of monopoly." A finding that a differential based upon cost is "unjustly discriminatory" would not be sustained by any court adopting the strict views here predicted and here recommended. It would be difficult to sustain on any theory. A finding based upon a theory that the larger discount is "promotive of monopoly" might have to be taken seriously, if based upon evidence. That problem may be faced when it arises. Only the most extensive proceedings could afford an adequate basis for an administrative order of this sort and a defendant would have ample opportunity to adapt himself to the new situation, if the evidence were going against him. This is not the sort of question that is causing business men present worry under the Robinson-Patman Act. There is no threat of triple damages involved.

Paragraph (b), placing upon the person charged the burden of justifying a discrimination proved at "any hearing on a complaint under this section," refers only to proceedings before the Federal Trade Commission. Pursuant to the Conformity Act, actions for damages would be started by declarations in some districts and by petitions in others and by pleadirgs bearing other designations in others, and it cannot be supposed that the law is o depend upon the names employed in the different jurisdictions. Furthermore, thr sole specified consequence of failure to rebut a prima facie case is that the Federal Trade Commission may issue an order to terminate the discrimination.

Paragraph (b) tends further to strengthen the argument that price differentials under paragraph (a) are not unlawful so long as they are no: discriminatory because unreasonable or otherwise against public policy. For the burden of justifying a dif- 
ferential upon a quantitative basis under the principles of cost accounting is utterly overwhelming and subversive of legitimate business practice. Cost accounting is not and cannot be an exact science. Fixed costs and variable costs incurred at the same time in connection with various products or various aspects of a business cannot be distributed in any manner demonstrably correct. A wide latitude must be allowed within which business judgment is to determine what accounting system to use and what discount policy to follow pursuant to the system chosen. If it be borne in mind, however, that no case is made out until a difference is shown to be prima facie unreasonable or against public policy, then the provision with reference to rebutting the prima facie case becomes declaratory of sound existing practice and consistent with the reasonable freedom to pursue a lawful calling associated with the Bill of Rights. In any event it must be clear that paragraph (b) is not an independent section of the law, but a mere subdivision of Section 2 of the Clayton Act as amended. It should be read in that context and, consequently, unless all the hurdles set up in that paragraph are cleared, paragraph (b) does not come into operation.

The last observation applies with reference to paragraphs (e) and (f), for the latter, subjecting the knowing beneficiaries of discrimination to liability, expressly refers to the rest of the section and paragraph (e) relates only to discriminatory differences in services furnished by the seller. Payments, not discriminations, are the subject of paragraphs (c) and (d), the former being directed against "dummy brokerage" payments and the latter against advertising allowances and the like when not available to all customers on "proportionally equal" terms. Consequently, although these paragraphs should be construed in pari materia with paragraph (a), the rule of reason or the discretionary control of the court based upon the suggested construction of the word "discrimination" does not there operate. It is not to be assumed, however, that all payments without consideration or all allowances made customers on terms which are not equivalent are to be unlawful. The policy of the Act is indicated in paragraph (a)-to protect various aspects of competition, and, unless one of the undesirable effects specified in paragraph (a) is established, the paragraphs probably have no operation.

Paragraphs (d) and (e) are vulnerable in that they fail to set up' any workable or intelligible standards for determining the meaning of the requirement that payments made or services furnished by sellers be open to all customers on "proportionally equal" terms. No guide is given concerning the variables that go to make up the proportion. Proportional to what? To the number of units sold? To the price? To the number of outlets commanded by the purchaser? To the need of the seller or purchaser for the particular sort of activity presumably promotive of distriburion? If a seller gives a thousand lines of advertizing to the purchaser of a million units, is he to give a line in the classified section to the purchaser of one thousand units? If he furnishes a demonstrator to the big purchaser for one thousand minutes is he to furnish a demonstrator to the little purchaser for 
one minute? He can scarcely furnish one-sixtieth of a demonstrator for an hour. Is it even clear that a straight arithmetic proportion is specified? How about geometric proportions? And upon what basis are the exponentials to be calculated?

The formal absurdity of the phrase "proportionally equal" has not yet been faced. If $\mathrm{W}$ is to $\mathrm{X}$ as $\mathrm{Y}$ is to $\mathrm{Z}$, the four quantities form a proportion and the two ratios are equal. Generally no two variables in a proportion are equal, however, for if any two of them are equal, the expression reduces to an identity, which suggests the immediate abandonment of the proportional form of statement. If $\mathrm{W}$ equals $\mathrm{X}$, a simple fact becomes an abortive horror by calling the quantities "proportionally equal." It would serve Congress right, if the courts flatly refused to have commerce with paragraphs simply not within any known language. A more likely result, though, is that the paragraphs will be allowed to stand as if Congress had required services or allowances to be roughly equivalent in view of all the circumstances. Even without the bulwark of a written Constitution, judges will decline to attempt the impossible. ${ }^{28}$ If there is no way of telling whether allowances are equivalent in view of all the circumstances, there is no way of finding a violation of the law.

It has generally been correctly assumed, it would seem, that Section 3 of the Robinson-Patman Act includes the only criminal provisions in that statute. At first glance the section would appear to be clearly unconstitutional. It is striking that this criminal provision lacks most of the qualifications and provisos that modify the paragraphs which carry only civil liability. To require equal discounts upon all sales involving like grade, quality and quantity would be to attempt to interfere with all private mercantile business in the same extensive manner that the law interferes with common carriers. ${ }^{28}$ The idea advanced with reference to paragraph (a) of Section 2 of the Clayton Act as amended, that the word "discrimination" is itself used only in an offensive sense does not, at first glance, apply with equal force to Section 3 of the Robinson-Patman Act. The former paragraph forbids discrimination where, etc., thereby indicating that the following language operates to limit the prohibition of the Act to those discriminations which, among many kinds of discriminations possible, satisfy the then following specifications. It makes no effort to define the sense in which the word "discrimination" is used. Section 3; on the other hand, forbids a sale which discriminates in that, etc., thereby inferentially expanding the concept of discrimination so as to include all unequal discounts. This intolerable construction might be avoided in various ways. The inferential definition might be frankily disregarded in the interests of constitutionality or the qualifications with reference to predatory motive in the last clauses of the paragraph might be carried back over a semicolon to modify the concept of discrimination employed in the first part of the section.

It does not follow, of course, that those who share the view that the Robinson-

${ }^{*}$ Statutes requiring the valuation in bankruptcy of contingent claims afford many examples, e.g., Robinson v. Ommanney, $21 \mathrm{Ch}$. D. 780 (1882) (covenant not to revoke a will); Vint v. Hudspith, 30 Ch. D. 24 (1885) (possibility of having to pay costs to assert a legal right); Ex parte Linton, I5 Q. B. D. 239 (1885) (funure liability for alimony). See, Wirtiston, Cases on Bankroptcr (1915) $481 \mathrm{n}$.

- Cf. $\$ 2$ of the Interstate Commerce Act, 4I STar. 479 (1920). 
Patman Act should, will and must be narrowly confined by the courts need conclude that the Act may be ignored. It will be a question whether intolerable effects of the Act should be met by frontal attacks or by evasion. One thing is quite clear. Attorneys cannot ethically advise their clients to evade the Act by lying. As one writer has suggested, there is no way to stop a seller from losing a hole in a golf match to his favorite customer. ${ }^{30}$ But checks can be traced and caddies and locker men may talk in a most irresponsible way about cash payments. Serious risks are incurred with any sort of false invoicing. The hurdles overcome by the plaintiff in the Ladoga Can case ${ }^{31}$ and its substantial recovery may be attributed in a large degree to the effect upon the court and jury of disingenuous conduct on the part of the defendant. A seller should supply himself with figures to give plausible accounting support to whatever discount policy he elects to pursue and should, if possible, promote that policy without attracting the attention of the legal ambulance chasers that will try to fatten on a harvest of triple damage suits.

On the whole, present indications are that the Federal Trade Commission can be relied upon to discredit the Act. Instead of endeavoring to find flagrant discriminators and to bring a few cases that might appeal to the courts, it has gone ahead without any signs of intelligent discrimination itself. Although no comprehensive information is here available, present indications are to the effect that these suits are badly chosen, ${ }^{32}$ and some, at least, are badly prepared and are being badly presented before the Commission. ${ }^{33}$ The large number of reversals of Federal Trade Commission orders that it is to be anticipated will encourage sellers to restore flexibility to their discount systems to such an extent that government enforcement of the law according to the construction of the sponsors of the Act would be a physical impossibility. The impracticability of such constructions must be soon made apparent to the courts in any event, but a good crop of reversals of Federal Trade Commission orders will accelerate the process of putting the Act in its proper place.

The courts can, of course, tend to the civil damage suits, not only by strict construction of the substantive law along lines similar to those here suggested, but also by requiring the plaintiff to demonstrate the causal connection between the alleged discrimination and the damages he claims. In most cases this is insusceptible of proof. Civil damage suits under the Anti-trust Laws have been, in general, abortive for this reason. ${ }^{84}$ The Supreme Court opened the door to such suits a few years ago in a case where the plaintiff had. suffered to an indeterminate extent from grossly predatory conduct. He was allowed to have a jury guess at his damages upon the theory that it was the defendant's fault that created the situation and that the defendant might accordingly have to bear the risk created by his act. ${ }^{35}$ This door can

'See Engel, The Patman Bill and Advertizing, Advertizing and Sezling, July 2, 1936, pp. $25,50$.

"1 Supra note 20.

a The discounts attacked in the matter of Kraft-Phenix Cheese Corp., Docket No. 2935, seem cminently reasonable.

$\$$ The record in the matter of Bird and Son, Inc., Docket No. 2937, seems to be a model of how not to prepare and try a case.

See McLaughlin, op. cit. supra note 15, at 37, 38, n.117, 569, n.179.

${ }^{25}$ Story Parchment Co. v. Paterson Parchment Paper Co., 282 U. S. 555 (193I). 
readily be closed, if suits for civil damages under the Robinson-Patman Act become a great source of wealth for speculative litigants.

If the courts are sufficiently impressed with the folly of subjecting a business man to the risk of triple damage suits every time he sells a bill of goods, the way lies open to a holding that there is no provision for such suits under the statute. Section 4 of the Clayton Act ${ }^{36}$ provides for damage suits under the "Anti-trust Laws," which are defined in Section $\mathrm{I}^{37}$ to include the Clayton Act, but they are nowhere defined to include the Robinson-Patman Act, amendments to the Clayton Act or the Clayton Act as amended. The Robinson-Patman Act, itself, not only fails to provide for suits by private parties but contains several other specific references to remedies. This invokes the principle that when a statute creates new rights or duties, the statutory remedies shall be exclusive. Thus, taking the sections of the Act in reverse order, Section 4, relating to dividends by cooperative associations, is an innocuous saving clause. Section 3 is clearly criminal only. Section 2 purports to deal only with the effect of the Act on past and pending Federal Trade Commission proceedings. The first section, amending Section 2 of the Clayton Act, contains, as we have seen, paragraph (b), which seems clearly to contemplate Federal Trade Commission proceedings only. The ambiguous new paragraphs making no references to procedure follow in its wake. The most conspicuous change in paragraph (a) purports only to confer new powers on the Federal Trade Commission. That paragraph is otherwise silent concerning procedure. Construing the entire RobinsonPatman Act by its four corners and reverting, if desired, to the "mischief to be remedied" ${ }^{38}$ and finding its source in a Federal Trade Commission investigation, ${ }^{39}$ it may be fairly urged that civil suits are unambiguously without the scope and without the contemplation of the Act.

Adoption of a few of the bolder strict constructions here suggested would render the Act so innocuous as to remove all occasion for further strict construction pursuant to the rule in Lord Cholmondeley's case. ${ }^{40}$ Trimming the Act into a workable pattern of commercial law may be achieved in a variety of ways. There is more doubt about the itinerary than about the destination. It seems safe to conclude that before long the harassed seller may be assured that cease and desist orders ain't a-goin' to rain no mo', for

The F. T. C., with R. P. wings,

Might soar to winged fame,

But C. C. A.'s, that have no wings,

Gan clip them just the same!

* 38 Stat. 731 .

78 Stat. 730.

* For a modern reference to this quaint test, see Atlantic Cleaners \& Dyers, Inc. v. U. S., 286 U..S. 427, 435 (1932), per Sutherland, J.

- Investigation of chain stores pursuant to SEN. REs. No. 224, 70th Cong., Ist Sess. (1928). See particularly Sen. Doc. No. 89, 73rd Cong., 2d Sess. (1933). See also supra note 24.

'Lord Cholmondeley was an apocryphal character who worried so hard he lost his memory and, losing his memory, forgot to worry. 

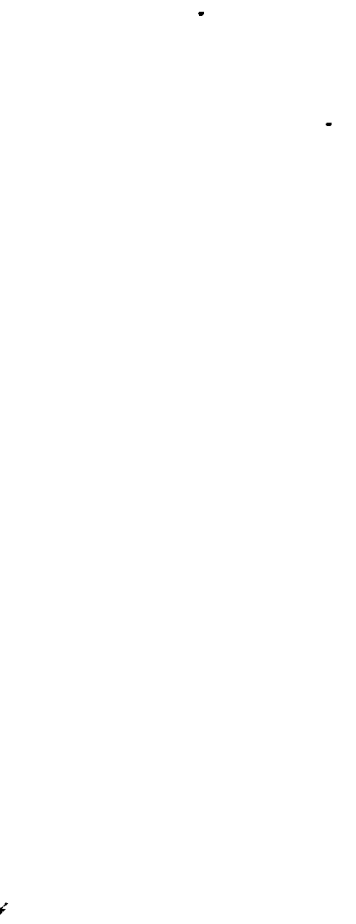